\title{
DNA 高次構造体の形成制御とナノ粒子アセンブリ
}

\author{
畠山 義治*1 $\cdot$ 南 昌宏*1 $\cdot$ 梅津 光央*1 \\ 大原 智*1 $\cdot$ 高見 誠一*1 $\cdot$ 阿尻 雅文*1
}

（受付 2004 年 5 月 31 日・審査終了 2004 年 7 月 26 日）

\begin{abstract}
要 旨 近年, バルク状態とは異なる物性を示すナノ粒子やカーボンナノ材料に関する研究が急速に発 展し，それらナノクラスターをアセンブリし機能発現を行うことが期待されている．本報では，DNAの 自己組織化を利用したナノ粒子パターニングを目標とし，一辺が約 $10 \mathrm{~nm}$ のひし形格子を一単位とした DNA 平面構造体の形成制御とそれを用いた金ナノ粒子のアセンブリを行った．DNA 平面構造体は，設 計された複数の一本鎖 DNAをアニール後徐冷することによって形成できるか，その徐冷過程を二本鎖 DNA の熱变性温度を考虑することによって，効率的に構造体を形成されることに今回成功した．また， その平面構造体形成過程に一本鎖 DNA 修飾金ナノ粒子を導入したところ, ナノ粒子に固定化した DNA 鎖と平面構造体中に設計した相補的塩基配列と結合を起こし，DNA 構造体をテンブレートとした金ナ， 粒子のアセンブリを観測できたことを報告する.
\end{abstract}

\section{1 緒言}

ナノレベルまで微細化した物質は，量子サイズ効果 などに起因する，バルク状態と異なる固有の物性を示 す1).そのため，これまでのマクロスコピックな物性を 組合せた機能発現に替わり，分子やクラスターが示す電 場・光応答性などを直接活用するナノユニットアセンブ リの研究が盛んに行われている2,3).

その中で, 高分子のもつ自己秩序化能を用いたナノ粒 子パターニングの開発が行われているが, DNA やタン パク質の生体分子をナノユニットの接合やアセンブリの テンプレートとした研究が近年報告されている. DNA は，互いに相補的な配列をもつ一本鎖が共通の軸を右方 向にらせんを巻き，中心軸に向かって配列した塩基が塩 基対則にしたがって皮素結合を形成している．Mirkin らは，一本鎖 DNA を金ナノ粒子に固定化し，DNAか もつ選択的な塩基対間の結合を利用して，ナノ粒子の可 逆的なアセンブリに成功しており ${ }^{4)}$ ，佐藤らは，ナノ粒 子上に固定化したDNAが二本鎖になるたけで，DNA の構造変化がナノ粒子の溶解性を下げ凝集体が形成され ることを示している5 .ささらに近年では，金ナノ粒子の 選択的多量体化 ${ }^{6)}$ や DNA ネットワークテンプレートを 用いた二次元アセンブリも報告されている7),8)。 また，

*1 東北大学多元物質科学研究所（980-8577 仙台市青葉区 片平 2 丁目 1-1)
Braun らは DNA 主鎖中のリン酸基に銀イオンを配位さ せた後，化学的還元を起こすことによって銀ナノワイヤ を作製しており9)，パラシウウムでも同様な報告がなされ ている ${ }^{10)}$.

このように DNA は，自己組織化能をむつ分子を取入 れたナノアセンブリとして最も用いられている一つであ るが, 近年 Seeman らによって非常に複雑な幾何学模様 をもつDNA ナノ構造体の構築が報告されている11)。 の一つに, 生体内の遗伝子変換の際にみられるホリデイ 連結結合を利用した，約 $10 \mathrm{~nm}$ の単位格子が規則配列 した網目構造がある ${ }^{12)}$.この構造は，設計された塩基配 列をもつ 8 本ないし 6 本の一本鎖 DNA が，四つのホリ デイ連結結合を角にしたナノ単位格子を形成し(Figure 1a)，さらに末端部分に残している単鎖部分 (Figure 1a 中囲い部分)を利用して隣接する他の単位格子と二次元 的に結合することによって形成される (Figure 1b).

Mao らは，この単鎖部分を残す個所を操作することに より，単位格子を 2 方向のみに展開した一次元構造体の 形成も可能であることを示している(Figure 1c) ${ }^{12)}$ ．筆 者らは, この DNA 高次構造体はナノデバイスのテンプ レートとして期待できると考えている. そこで今回，ホ リデイ連結構造を利用した DNA 高次構造体のナノデバ イステンプレートへの適用を考え，その形成過程の制御 と，それを鋳型とした金ナノ粒子のアセンブリを行った 研究を報告する. 


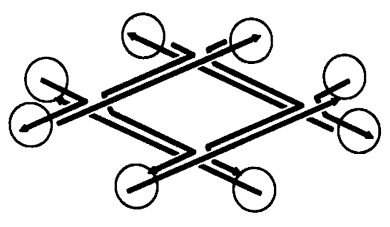

(a)

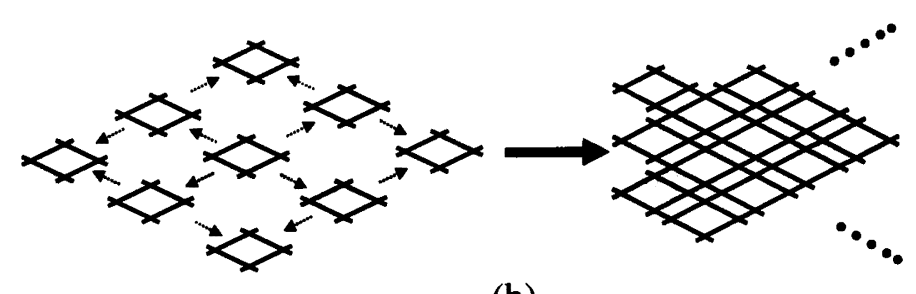

(b)

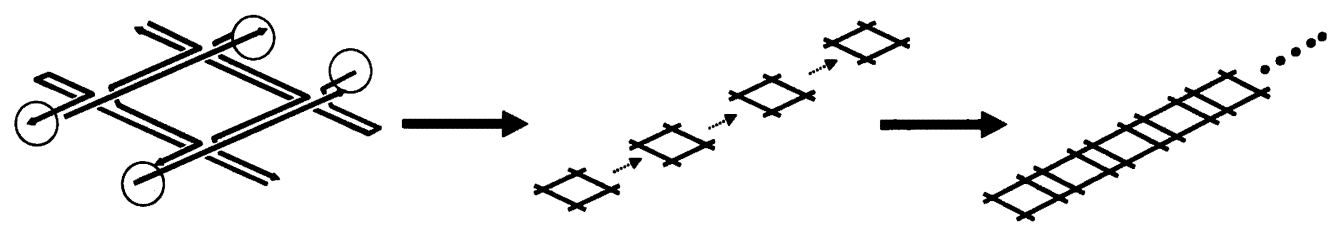

(c)

Figure 1. Schematic representation of DNA assembly (Ref. 12). (a) A view of a square unit composed of 8 DNA strands. The circled single strand is designed for binding to neighboring units. (b) The formation of a DNA plane conformation from the square units. (c) The formation of an one-dimensional assembly from the square units. The circles in (a) and (b) represent the binding sites between the square units.

Table 1. DNA sequences used for the template of gold nano-particle assembly ${ }^{\mathrm{a}}$

\author{
Strand a $(98 \mathrm{mer})^{\mathrm{a})}$ \\ 5'-ACGTGTTCCCGGGAGCTGATAGGACAATGAGTAGCTATTGGTGATCAACGTTAAGATACCAGTGGACGAATCGTTTTC \\ GATTCGTGGCTGTCAGTGAG-3' \\ Strand b (93 mer) \\ 5'-CAATGCTCACTCACCATAGAATTCGTTTTTACGAATTCTATGGACGTAGATACTGTGCTAACGATATTCGAACTAGCGT \\ CATCGGACGATCAG-3' \\ Strand c (63 mer) \\ 5'-CATTGGTAGTGCCTGTAATAATGTTGACTGCGGTTACCGTACTAATTGCTGTACCTGAGTGAG-3' \\ Strand d (63 mer) \\ 5'-TGACAGCCTGTCGAGTAGATCGTATGAATAGATGGCATCGCTGTAAATCCTGTGTCACCTCAC-3' \\ Strand e (100 mer) \\ 5'-GTGACACACCGATGACGCTAGTTCGAATATCGTTAGCACAGTATCTACGTGGTACAGCAATTAGTACGGTAACCGCAG \\ TCAACATTATTACACCTATCAG-3' \\ Strand $\mathrm{f}(115 \mathrm{mer})^{\mathrm{a})}$ \\ 5'-ACGTGTTCCCGGGAGCTGATCGTGGATTTACAGCGATGCCATCTATTCATACGATCTACTCGACACCACTGGTATCTTA \\ ACGTTGATCACCAATAGCTACTCATTGTGGCACTAC-3' \\ Strand $g(15 \mathrm{mer})^{\mathrm{a})}$ \\ 5'-CTCCCGGGAACACGT-SH-3'
}

a) The DNA sequences are the same as those reported by Mao et al. ${ }^{12)}$ except for the sequences underlined in strands a, $f$, and $g$. The underlined sequences in the strands a and $f$ are complementary to that of strand $g$.

\section{2 実験方法}

\section{1 二次元展開 DNA 高次構造体の作製}

Maoらによって報告されている8 本の一本鎖 DNA (文献 12)中 strand 1 8) を $50 \mathrm{mM}$ \{2-[4-(2-ヒドロキシ エチル)-1-ピペラシニル]エタンスルホン酸\} (HEPES)塩酸緩衝液 $\left(\mathrm{pH} 7.0,4 \mathrm{mM} \mathrm{MgCl}_{2}, 1 \mathrm{mM}\right.$ EDTA)にそ
れぞれ溶解し，最終 DNA 濃度を $100 \mathrm{nM}$ とした。それ ら DNA 水溶液をそれぞれ等量混合し，90 $90^{\circ} \mathrm{C} 10$ 分間了 ニール後, さまさまな速度で徐冷を行った．

2.2 一次元 DNA 構造体をテンプレートとした金ナ ノ粒子アセンブリ

Table 1にMao らによって設計された一次元に構造

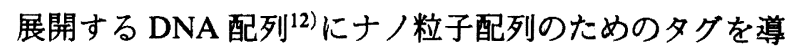




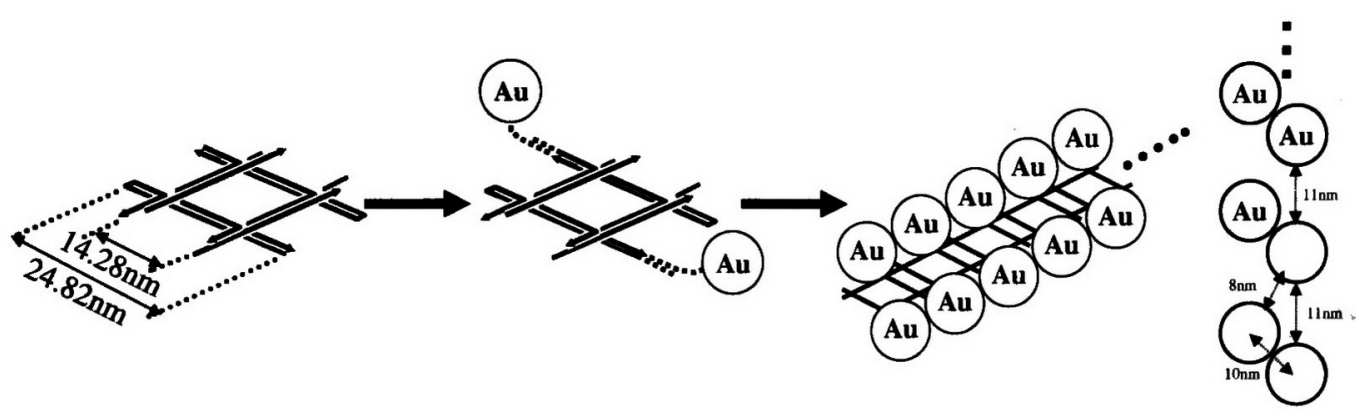

(a)

(b)

(c)

(d)

Figure 2. Au nano particle assembly on the one-dimensional DNA conformation. (a) The square unit designed for the one-dimensional assembly. (b) The square unit with two binding sites for DNA-modified Au nano particles. (c) Au nano particle assembly based on the square units of (b). (d) The top view of the Au nano particle assembly of (c).

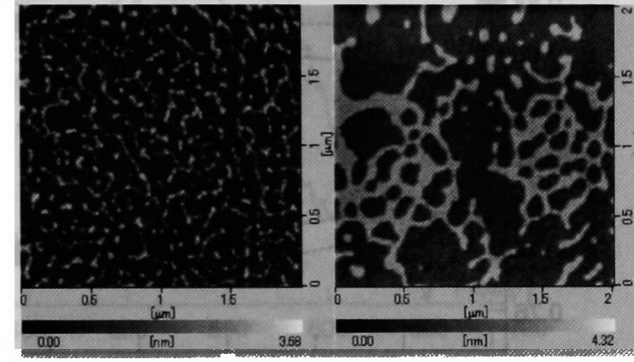

(a) $2^{\circ} \mathrm{C} / 1 \mathrm{~min}$

(b) $2^{\circ} \mathrm{C} / 4 \mathrm{~min}$

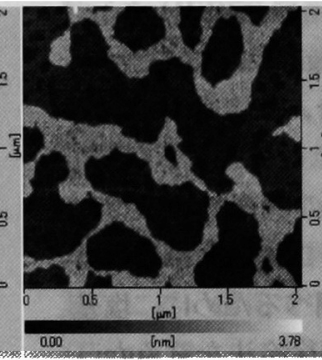

(c) $2^{\circ} \mathrm{C} / 8 \mathrm{~min}$

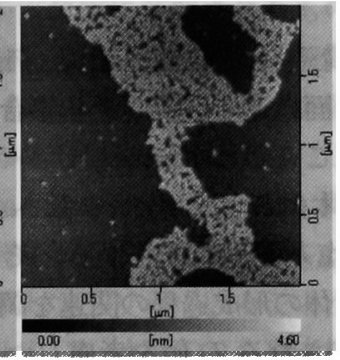

(d) $2^{\circ} \mathrm{C} / 18 \mathrm{~min}$

Figure 3. AFM images of the DNA "plane" conformation formed at the cooling rates of (a) $2^{\circ} \mathrm{C} / 1$ $\min$, (b) $2^{\circ} \mathrm{C} / 4 \mathrm{~min}$, (c) $2^{\circ} \mathrm{C} / 8 \mathrm{~min}$, and $\left(\right.$ d) $2^{\circ} \mathrm{C} / 18 \mathrm{~min}$, respectively.

入した DNA 配列(strand a〜f)を示すここれら DNA 鎖 を用いることにより，導入したタグ( と相補的な DNA 鎖 (Table 1 中 strand g) を修飾した金 ナノ粒子が単位格子(Figure 2a)の対角線上に配置され (Figure 2b)，その単位格子どうしが連結することによ り金ナノ粒子の 2 列アセンブリが形成されることが予 想される(Figure 2c). まず， $3^{\prime}$ 末端にチオール基が導入 されている strand $\mathrm{g} の 10 \mathrm{mM}$ 水溶液 $\left(10 \mathrm{mM} \mathrm{NaH}_{2} \mathrm{PO}_{4}\right.$, $1 \mathrm{mM}$ EDTA, pH 7.0) $300 \mu \mathrm{L}$ を $11.5 \mathrm{nM}$ 金ナノ粒子水 溶液 (直径 $10 \mathrm{~nm}$, シグマ) $1 \mathrm{~mL}$ に加え, DNA 修飾金 ナノ粒子を調製した。 そして, strand $\mathrm{a} \sim \mathrm{f}$ は各々 50 mM HEPES-塩酸楥衝液 $(\mathrm{pH} 7.0,4 \mathrm{mM} \mathrm{MgCl}, 1 \mathrm{mM}$ EDTA)に最終濃度 $100 \mathrm{nM}$ になるように溶解し，DNA 修飾金ナノ粒子と等濃度になるようすべてを混合した。 最後に，その混合溶液を $90^{\circ} \mathrm{C} 10$ 分間アニール後, $2^{\circ} \mathrm{C} /$ 18 分の速度で徐冷した.

\section{3 原子間力顕微鏡(AFM) 測定}

$10 \mu \mathrm{L}$ の試料溶液を壁開マイカ上へ滴下し， 5 分間放 置することにより DNA 高次構造をマイカ表面上へ固定 化した. 塩を取除くためマイカ基板上へ $100 \mu \mathrm{L} の \mathrm{H}_{2} \mathrm{O}$
を滴下し，10 秒間浸した後除去した．この操作を 2 度 繰返し, 乾燥させた. 作製した試料は, 走査型プローブ 䫓微鏡(Seiko Instruments Inc. 製)に NSCチップ(MikronMacsh, Inc. 製)を用いて,タッピングモードによりイメ ージングを行った.

\section{4 透過型電子顕微鏡 (TEM) 測定}

$2 \mu \mathrm{L}$ の試料溶液をグリッド(Nisshin EM Co. Ltd. 製) 上へ滴下し, 真空乾燥を行った. グリッド上に滴下・乾 燥した金ナノ粒子の配列・分散状況を TEM (Carl Zeiss Inc. 製，LEO-912-AB 型)により観察した.

\section{3 結果と考察}

\section{1 二次元 DNA 構造の温度制御による広域化}

Figure 3 に二次元展開する一本鎖 DNA strand 1 12) $^{12}$ を混合した水溶液を $90^{\circ} \mathrm{C} 10$ 分間アニーリングした後, さまざまな速度で $4^{\circ} \mathrm{C}$ まで徐冷した時の AFM 画像を示 す. Figure $3 \mathrm{a} よ り, 2^{\circ} \mathrm{C} / 1$ 分の速度で徐冷した場合, ひむ状の構造のみが観測され，広域な平面構造体は見ら れなかった. しかし，徐冷速度を徐々に遅くしていく と,ひも状構造が粰がり始め $2^{\circ} \mathrm{C} / 18$ 分では，数 $\mu \mathrm{m}$ の 


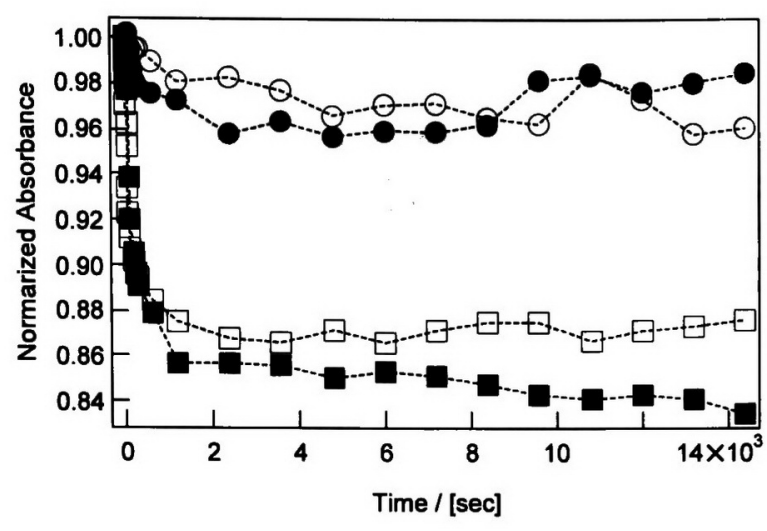

Figure 4. The change of the absorbance at $260 \mathrm{~nm}$ by cooling from $90^{\circ} \mathrm{C}$ to $80^{\circ} \mathrm{C}$ (open circle), $70^{\circ} \mathrm{C}$ (closed circle), $60^{\circ} \mathrm{C}$ (open square), and $50^{\circ} \mathrm{C}$ (closed square), respectively. The absorbance is normalized by the value at the start point.

広域な平面構造体が観測された(Figure 3d)。これよ り，広域な平面構造を形成させる場合，徐冷速度の制御 が重要であることがわかる.

DNAの二本鎖構造から一本鎖への熱変性温度 $\left(T_{\mathrm{m}}\right.$ 値)は，その塩基配列に依存する．そこで，徐冷過程と 広域平面構造体の形成過程の関連を調べるために，塩基 配列から想定される $T_{\mathrm{m}}$ 値を考虑した徐冷法を試みた。 DNA の塩基に起因する $260 \mathrm{~nm}$ の吸収帯は二本鎖を組 むことにより，その吸光度を下げる、そこですず初め に, 単位格子(Figure 1a) 1 辺の二本鎖に対する $T_{\mathrm{m}}$ 値を Wallace らの計算式 ${ }^{13)}$ 加 $69 \sim 72^{\circ} \mathrm{C}$ と予想されること を考虑し, $90^{\circ} \mathrm{C}$ アニール後 DNA 溶液を $80^{\circ} \mathrm{C}$ から $50^{\circ} \mathrm{C}$ の各温度へ保持した時の経時变化を $260 \mathrm{~nm}$ の吸光度で 追跡した(Figure 4). その場合, $80^{\circ} \mathrm{C}$ と $70^{\circ} \mathrm{C}$ まて徐冷 したものはほとんど吸光度が減少していないのに対し (Figure 4 中○，○，60 $60^{\circ} \mathrm{C}$ と $50^{\circ} \mathrm{C}$ まで徐冷したものは 减少しているのが明確に観測された (Figure 4 中 $\square$,

口).さらに, 各温度で 4 時間経過した DNA 水溶液を $4^{\circ} \mathrm{C}$ へ急冷し AFM で観測したところ(Figure 5), $80^{\circ} \mathrm{C}$ から急冾した DNA は，ほとんど構造形成が観測されな かったのに対し (Figure 5a), $60^{\circ} \mathrm{C}$ から急冷したもので は, $90^{\circ} \mathrm{C}$ から $2^{\circ} \mathrm{C} / 1$ 分の速度で徐冷した時 (Figure 3a) と同様なひむ状の構造が形成されていた(Figure 5b).

このことから, 単位格子の形成よりも徐冷が速い場合 は，DNA 構造物はほとんど観測されないといえる.

次に, 単位格子間の連結と徐冷速度の関連を調べるた めに, DNA 溶液を $90^{\circ} \mathrm{C}$ アニール後 $60^{\circ} \mathrm{C}$ で 4 時間保持 し単位格子を形成させた後, $50^{\circ} \mathrm{C}$ から $10^{\circ} \mathrm{C}$ までの各温 度で保持した時の吸光度を測定した(Figure 6). その場 合, $30^{\circ} \mathrm{C}$ までは $260 \mathrm{~nm}$ の吸光度は減少しないのに対し て(Figure 6 中 $\bigcirc, \square, \square$ ), $20^{\circ} \mathrm{C}$ と $10^{\circ} \mathrm{C}$ まで徐冷した DNA の吸光度は減少し, 新たな二重鎖の形成を示した

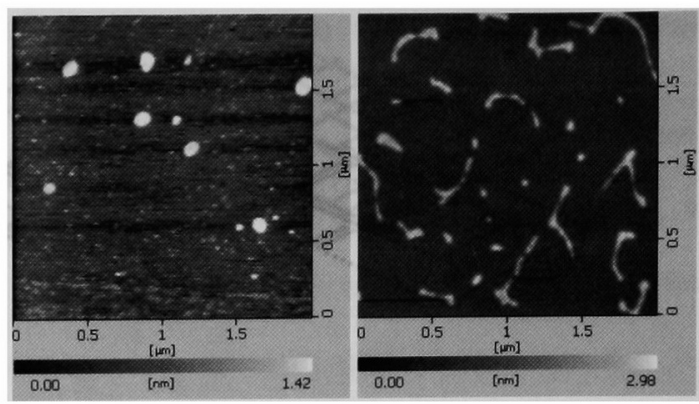

(a)

(b)

Figure 5. AFM images of DNA conformation formed by cooling to $4^{\circ} \mathrm{C}$ after keeping the temperature at (a) $80^{\circ} \mathrm{C}$ or (b) $60^{\circ} \mathrm{C}$ for 4 hours.

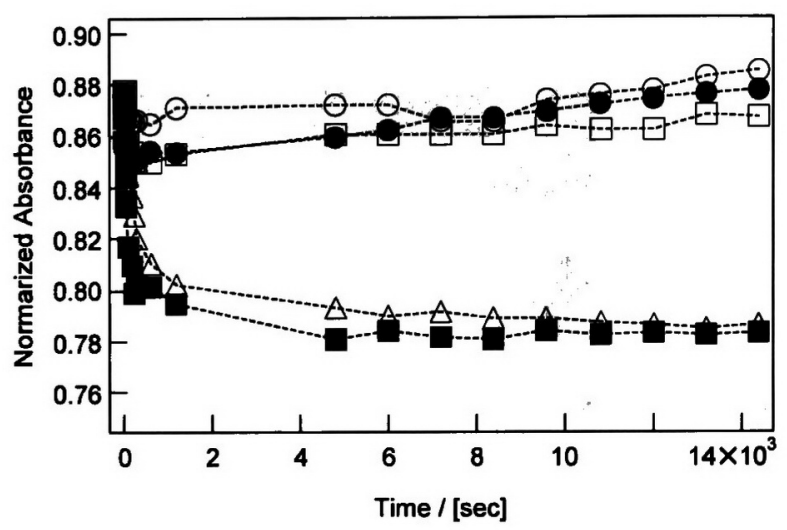

Figure 6. The change of the absorbance at $260 \mathrm{~nm}$ by cooling from $60^{\circ} \mathrm{C}$ to $50^{\circ} \mathrm{C}$ (open circle), $40^{\circ} \mathrm{C}$ (closed circle), $30^{\circ} \mathrm{C}$ (open square), $20^{\circ} \mathrm{C}$ (closed square), $10^{\circ} \mathrm{C}$ (open triangle), respectively, after keeping the temperature at $60^{\circ} \mathrm{C}$ for $4 \mathrm{~h}$. The absorbance is normalized by the value at $90^{\circ} \mathrm{C}$.

(Figure 6 中日, $\triangle$ ). 単位格子間を連結する末端部分に ある単鎖の予想 $T_{\mathrm{m}}$ 值が $14 \sim 26^{\circ} \mathrm{C}$ であることを考える と, $20^{\circ} \mathrm{C}$ までの徐冷で単位格子が連結していくことが 示唆される.そこで,これまでの結果を基に, より広域 な DNA 平面構造体を形成させるために, $60^{\circ} \mathrm{C}$ と $20^{\circ} \mathrm{C}$ に温度保持過程を導入し, 他の過程での徐冷は $40^{\circ} \mathrm{C} /$ 分

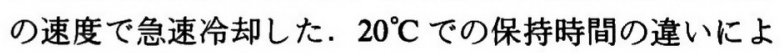
る DNA 構造体の変化を AFM で観測したところ(Figure 7), 保持時間が長くなるにつれて DNA 平面構造体が広 域化していくことがわかる.これは, 長く $20^{\circ} \mathrm{C}$ に保持 することによって, 単位格子間の結合が促進していくこ とを示す. また, $60^{\circ} \mathrm{C}$ と $20^{\circ} \mathrm{C}$ の温度保持過程以外での 徐冷速度は Figure 3d の場合よりも非常に速いにもかか わらず, $20^{\circ} \mathrm{C}$ での保持時間が 10 分を越えると構造の広 域化は $2^{\circ} \mathrm{C} / 18$ 分のもの (Figure 3d) を越えている(Figure 7c).このことから, 単位格子形成過程と単位格子連結 過程を制御することが DNA 構造の広域化に最も重要で 


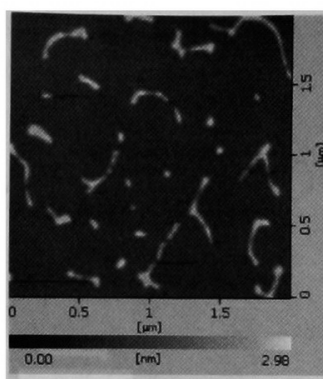

(a) $0 \mathrm{sec}$

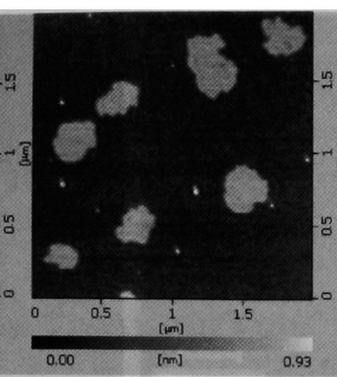

(b) $5 \mathrm{~min}$

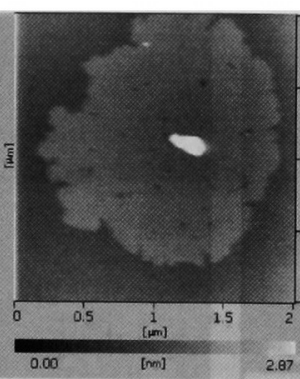

(c) $10 \mathrm{~min}$

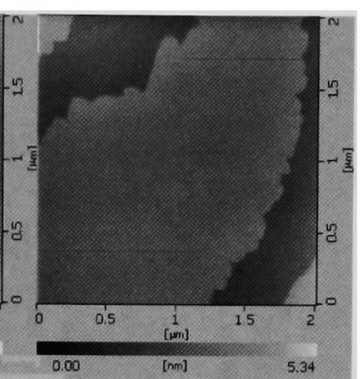

(d) $15 \mathrm{~min}$

Figure 7. AFM images of the DNA "plane" conformation. Each conformation was formed by cooling at the rate of $40^{\circ} \mathrm{C} / \mathrm{min}$ with the retention times at 60 for $4 \mathrm{~h}$ and at $20^{\circ} \mathrm{C}$ for (a) 0, (b) $5 \mathrm{~min}$, (c) $10 \mathrm{~min}$, and (d) $15 \mathrm{~min}$, respectively.

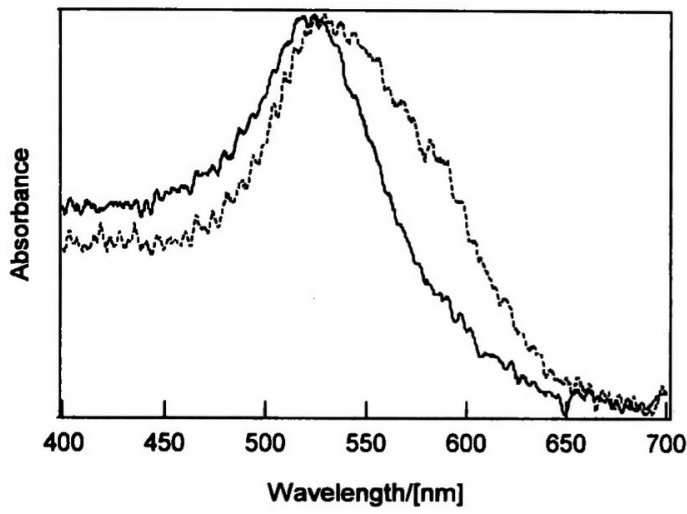

Figure 8. Absorption spectra for dispersed gold nano particles (solid line) and gold nano particles assembled by DNA conformation (dashed line) in a $5 \mathrm{mM}$ HEPES buffer ( $\mathrm{pH}$ 7.0, $2 \mathrm{mM} \mathrm{MgCl} 2,0.5 \mathrm{mM}$ EDTA).

あり，それらを制御することによって，DNA 平面構造 成長を操作できるといえる.

\section{2 一次元 DNA 構造上への金ナノ粒子の固定化}

まず初めに，DNA 修飾した金ナノ粒子を一次元に展 開する DNA 配列( strand a e ) と混合し高次構造を形成 後，金ナノ粒子のプラズモン吸収を測定した (Figure 8). その結果，DNA 修飾金ナノ粒子の及を分散させた HEPES 緩衝水溶液は，DNAが金表面に固定化されて いるため㠜集を起こさず $520 \mathrm{~nm}$ 付近にプラズモン吸収 を示した (Figure 8 中実線). しかし, strand $\mathrm{a} \sim \mathrm{f}$ の DNA を加え，アニール・徐冷 $\left(2^{\circ} \mathrm{C} / 18\right.$ 分)すると 580 $\mathrm{nm}$ 付近に新たなプラズモン吸収が現れることがわかっ た(Figure 8 中破線)。このシフトは, DNA 修飾金ナ， 粒子のみをアニール・徐冷したり, DNA 修飾金ナノ粒 子に DNA 鎖 strand $\mathrm{a} \sim \mathrm{f}$ (Table 1)を加えたのみでは観 測されなかった．プラズモン吸収は金ナノ粒子が凝集す ると長波長側へシフトすることを考えると, strand $\mathrm{a} \sim \mathrm{f}$ を加え DNA に高次構造を形成させることによって，金 ナノ粒子がアセンブリされていることを示唆する.
次に，上記試料の TEM 画像を観測した (Figure 9). まず，DNA が未修飾の金ナノ粒子と DNA 修飾金ナ， 粒子を HEPES 緩衝水溶液に分散させたものを観測して みたところ，未修飾のものは規則性なく凝集しているが (Figure 9a), DNA 修飾金ナノ粒子は, 凝集せずに分散 していることがわかる(Figure 9b)。一方, DNA 修飾金 ナノ粒子に strand $\mathrm{a} \sim \mathrm{f}$ の DNA 鎖を加え構造形成させ たものは，金ナノ粒子が分散しておらず，比較的直線で 設計に近い構造でアセンブリしていることが観測された (Figure 9c).これより，一次元 DNA 高次構造がテンプ レートとして金ナノ粒子のアセンブリを制御していると 考えられる. Figure 2d の金ナノ粒子の予想アセンブリ を見ると, 一つの格子に配置する金ナノ粒子はほとんど 接しているが, 格子間では $11 \mathrm{~nm}$ の間隔で粒子が配置 されている，一方，Figure 9cでは，金ナノ粒子が間隔 をあけずに 2 列配列を形成している。これは，DNA 格 子により金ナノ粒子が連結された結果，近接するナノ粒 子間の相互作用が働きナノ粒子間の間隔が小さくなった ためと現在考えている.

\section{4 結 言}

筆者らは，Maoなど(2)が報告している DNA の平面 構造体をナノ粒子アセンブリのテンプレートとして用い る手法を考案した．そのため，まずその DNA 平面構造 体の構造形成過程を解析し， $T_{\mathrm{m}}$ 温度を考虑した構造形 成制御法に成功した：そして，ナノ粒子を配置する場所 をあらかじめ一次元 DNA 構造体に設計することによっ て,ナノ粒子をある程度規則的にアセンブリすることが 可能であることがわかった.

謝辞本研究は, 文部省科学研究費補助金萌芽研究 （16656237）より行った。 また，日産科学振興財団からの資金提 供に心から感謝いたします．AFM 機器の利用に関して，東北 大学の三箇山毅博士に感謝いたします. 


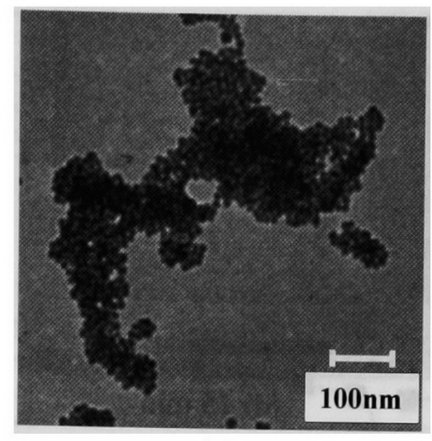

(a)

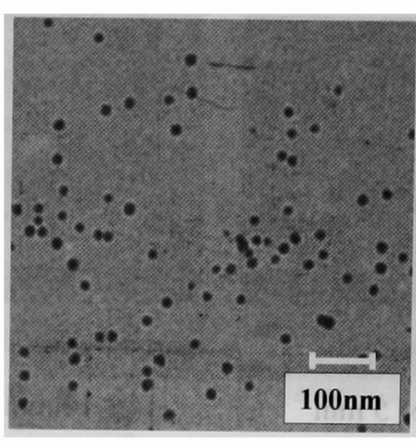

(b)

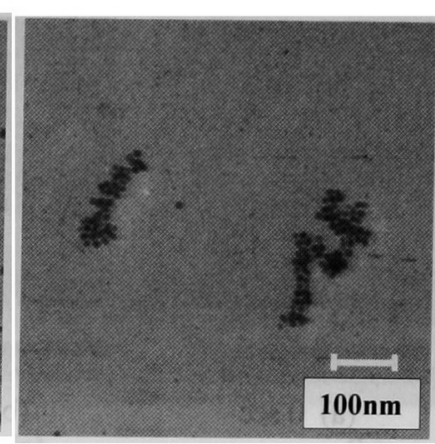

(c)

Figure 9. TEM images of (a) Au nano particles after dispersion in a $5 \mathrm{mM}$ HEPES buffer ( $\mathrm{pH} 7.0,2$ $\mathrm{mM} \mathrm{MgCl}, 0.5 \mathrm{mM}$ EDTA), (b) DNA-modified Au nano particles after dispersion in the HEPES buffer, (c) DNA-modified Au nano particles which are annealed at $90^{\circ} \mathrm{C}$ with DNA strands a-e and then cooled at the ratio of $2^{\circ} \mathrm{C} / 18 \mathrm{~min}$.

\section{文献}

1) A. P. Alivisatos, Science, 271, 933, (1996).

2) C. Dwyer, M. Guthold, M. Falvo, S. Washburn, R. Superfine, and D. Erie, Nanotechnology, 13, 601 (2002).

3) T. Yonezawa, K. Imamura, and N. Kimizuka, Langmuir, 17, 4701 (2001).

4) C. A. Mirkin, R. L. Letsinger, R. C. Mucic, and J. J. Storhoff, Nature, 382, 607 (1996).

5) K. Sato, K. Hosokawa, and M. Maeda, J. Am. Chem. Soc., 125, 8102 (2003).

6) D. Iacopino, A. Ongaro, L. Nagle, R. Eritja, and D. Fitzmaurice, Nanotechnology, 14, 447 (2003).

7) Y. Maeda, T. Nakamura, K. Uchimura, T. Matsumoto, H. Tabata, and T. Kawai, J. Vac. Sci. Technol. B, 17, 494 (1999).
8) Y. Maeda, H. Tabata, and T. Kawai, Appl. Phys. Lett., 79, 1181 (2001).

9) E. Braun, Y. Eichen, U. Sivan, and G. B.Yoseph, Nature, 391, 775 (1998).

10) J. Richter, R. Seidel, R. Kirsch, M. Mertig, W. Pompe, J. Plaschke, and H. K. Schackert, Adv. Mater., 12, 507 (2000).

11) N. C. Seeman, Ann. Rev. Biomol. Struct., 27, 225 (1998).

12) C. Mao, W. Sun, and N. C. Seeman, J. Am. Chem. Soc., 121, 5437 (1999).

13) R. B. Wallace, J. Shaffer, R. F. Murphy, J. Bonner, T. Hirose, and K. Itakura, Nucleic Acid Res., 6, 3543 (1979).

\begin{abstract}
Control of Designed High-Order DNA Conformation as a Template for Nano Particle Assembly
Yoshiharu HatakeYama, ${ }^{* 1}$ Masahiro Minami, ${ }^{* 1}$ Satoshi Ohara, ${ }^{* 1}$ Mitsuo Umetsu, ${ }^{* 1}$ Seiichi Takami, ${ }^{* 1}$ and Tadafumi Adschiri ${ }^{* 1}$

${ }^{* 1}$ Institute of Multidisciplinary Research for Advanced Materials, Tohoku University (2-1-1 Katahira, Aoba-ku, Sendai 980-8577, Japan)

Highly selective base-pairing rules in DNA can be utilized as a tool for assembling nano particles. Holliday Junctions, where two different DNA double strands intersect and replace the complement strand, are an important artificial motif for forming two-dimensional "plane" conformations of DNA. In this study, we controlled the growth of the DNA "plane" conformations by changing the temperature. A set of DNA single chains were cooled from $90^{\circ} \mathrm{C}$ to $4^{\circ} \mathrm{C}$ for 10 minutes, to form the DNA "plane" conformation. The influence of the cooling procedure on the DNA conformation was observed by atomic force microscope (AFM). The DNA "plane" conformation is strongly dependent on the cooling process. Further, we assembled gold nano particle using the DNA conformation; then we observed the assembly of gold nano particle on the DNA conformation by transmission electron microscopy (TEM).

KEY WORDS DNA / Assembly / Nano Particles /
\end{abstract}

(Received May 31, 2004: Accepted July 26, 2004)

[Kobunshi Ronbunshu, 61(12), 617-622 (2004)] 